pag

Business School

WORKING PAPER SERIES

\begin{tabular}{c|l} 
Working Paper & $\begin{array}{l}\text { Transformation and Perception: } \\
\text { How an Information System Project } \\
\text { Can Be Carried out Successfully }\end{array}$ \\
Dorota Leszczyńska \\
Laurence Saglietto
\end{tabular}

http://www.ipag.fr/fr/accueil/la-recherche/publications-WP.html

IPAG Business School

184, Boulevard Saint-Germain

75006 Paris

France 


\title{
Transformation and Perception: How an Information System Project Can Be Carried out Successfully
}

\author{
Dorota Leszczyńska $^{1}$ and Laurence Saglietto ${ }^{2}$ \\ ${ }^{1}$ IPAG Ecole Supérieure de Commerce-Nice Laboratory GREDEG UMR CNRS 6227, France \\ ${ }^{2}$ University of Nice Sophia Antipolis Laboratory GREDEG UMR CNRS 6227, France
}

\begin{abstract}
Perception is not taken into account at its true value by the research work on organisational transformation.The aim of this publication is to put forward an analysis of the critical first stage of organizational transformation (first phase). We think there is a link between the first stage of transformation, its perception by the actors, and the success of the implementation of the project. We therefore put forward a conceptual model, which we shall illustrate with two casestudies in information systems and a discussion.
\end{abstract}

Keywords: Organizational Transformation (first phase), Organizational Perception, Success, Information System

\section{Introduction}

Even though perception is a concept which is necessarily intuitive in the analysis of transformations in information systems, it is not taken into account at its fair value in existing theoretical models. These models mainly deal with the following triptych: Intelligence (formulation of the problem) , Design (conception of alternatives) and Choice (choice of a solution) (Simon 1976). However, the development of systems adapted to each phase of the decisionmaking process represents today a major challenge in information systems (Kivijärvi, 1997, Markus \& Tanis, 2000. We will therefore focus on the first phase of a transformation: its perception. Very little mentioned in theoretical inputs, this phase is yet fundamentally linked to future organizational impacts of a project (Rowe and Besson, 2001: p. 5).

Thus, research has shown that the perception at the beginning of the transformation by the actors impacts the process of its establishment (Gellis, 2001) and increases the commitment to work (Leach, 2005) and the performance of the work (Rosen \& al, 2006). Indeed, perception consists in undergoing an action and responding appropriately (Elsbach, 2006). However, there has been little research in management of transformation which examines the psychological mechanisms of perception (Chang \& al, 2009: p. 780). Some works in cognitive psychology (Piaget, 1967) however provide a framework conducive to remedying this deficiency. This is particularly the case in recent advances on emotional experiences (Efenbein \& al, 2007; Armenakis \& al, 2007; Weick \& al., 2005). The purpose of our research is therefore an attempt to understand how theoretical inputs in the processing field, on the one hand, and in the psycho-cognitive field of perception, on the other hand, can articulate and be mutually beneficial.

Copyright (C) 2011 Dorota Leszczyńska and Laurence Saglietto. This is an open access article distributed under the Creative Commons Attribution License unported 3.0, which permits unrestricted use, distribution, and reproduction in any medium, provided that original work is properly cited. Contact author: Dorota leszczyŃska E-mail: dorota.leszczynska@club-internet.fr 
From this analysis, the question that drives our thinking can be formulated thus: how can a manager and his project team express their way of seeing the first phase of organizational transformation? We identify, in the first part, the concepts of organizational transformation and organizational perception to highlight the interest of their close connection, so as to apprehend a more overall transformation in the information system projects.

In the second part, we build a conceptual model of the main psychological mechanisms that connect organizational perception to the results of the transformation and illustrate it with two case-studies.

Finally, in the third part, we note that there is a link between perception, the first phase of organizational transformation and the success of a project in information system. Therefore, it is at this stage that managerial interest will be meaningful. We will undertake a discussion on this link.

\section{"Organizational Transformation" and "Organizational Perception": A Successful Connection}

Organizational transformation represents the phases of realignment of the strategy, the structures and the processes of the organization and the behaviour of the actors. Specifically, the transformation process involves the following three phases:

- a state of full readiness leading to the first phase,

- the adoption and

- the institutionalization (Armenakis and Harris, 2002: p.169) of the project

During the first phase, the actors are prepared for the processing and (ideally) become followers. Thus, the success of the organizational transformation is linked to the perception of this initial phase (Chang $\& \mathrm{al}, 2009$ ). Therefore, it is likely that the management methods used to launch the first phase of a transformation differ from those used in subsequent phases.

\section{Organizational Transformation}

The transformation is often referred to by terms of organizational changes (Coghlan, 2000) or reengineering (Hammer and Champy, 1993) and linked to related concepts such as leadership or the concept of resources and competencies (Burns, 1978); Gilmartin \& D'aunno, 2008). Two lines of theoretical research determine the boundaries of the transformation without offering a specific reading grid of management for the first phase of organizational transformation. It is important to briefly trace the essential ideas and the boundaries of these two currents before sharing our point of view.

Firstly, the contextual approach representing an aspect of the processing situation (Hull and al, 1997) circumscribes the phenomenon. However, the contextual approach in the work in information systems is limited to the accumulation and transmission of preconceived knowledge without taking into account the psychological and emotional state of the actors (Dey and Abowd, 1999).

This approach is interesting because it specifies the transformation perimeter. The context, defined as an environment for performing tasks, is measured through indicators of: places, actors identities, activities and time (Dey and Abowd, 1999). The mobilization of those indicators provides different faces of the "context" concept as a critical factor in overall teamwork performance (Rotundo and Sackett, 2002) and facilitator of organizational transformation (Milton and Westphal, processing 2005; Van der Vegt and Bunderson, 2005). This increases the belief of the team in the fact that the work is significant (Baron and Hannan, 2002, Bierly et al, 2000). Regarding this last aspect, Rowe and Besson (2001) point out, in a study on the dynamics of information systems projects, that the strategic maturity of the actors can be evaluated on the basis of their level of understanding of the consequences for the organization. In 
this case, the first phase of processing is directly concerned.

Secondly, the conduct of organizational transformation is analysed mainly through the theory of leadership in two forms: transformational (Burns, 1978; Bass, 1985; Gilmartin and D'aunno, 2008) and emotionally intelligent (Cummings \& al., 2005; Huy, 1999). This theory allows us to partially fill the limits of the contextual approach taking into account the actors emotions. Transformational leadership is positively and significantly related to staff/job satisfaction, to additional effort (Gellis, 2001), to performance unity perceived (Stordeur \& al, 2000), to a favourable organizational climate (Corrigan et al., 2002), to organizational commitment and, finally, to the conservation of the staff (Leach, 2005). Studies point out that cascading transformations in leadership (Bass, 1985), the upper echelons of the hierarchy managers behave in a more transformational way than those with lower hierarchical position (Leach, 2005). With regards to studies that examine the role of leaders in the management of emotions in the workplace (Huy, 1999; Cummings \& al., 2005; Haag and Laroche, 2009), they point out that an emotionally intelligent leader, open to others, generates increased reactions of satisfaction and dedication on the part of his staff. The feeling of "positive emotions" determines the level of performance seen in the project. According to Haag and Laroche (2009: p. 85), "positive emotions occur when the actual performance is close to the performance to which we aspire". Research results also show that this type of management creates fewer negative effects when restructuring an organization. Kan and Parry (2004) specify in this regard that if the leadership style is a key factor of organizational transformation, the structure and organizational culture, and particularly resistance to change, are also very important. The work of Harvey et al. (2006) refines these analyses taking an interest in stimuli and cognitive, motivational and emotional processes causing a change in organizational behaviour at the implementation of a project in information system.

In summary, it is therefore important to go beyond the context and the leadership aspect to fully identify the first phase of transformation of a project. Indeed, the managers adopt, during this phase of the process (with a perception of the potential benefits), a specific style of management (Rowe and Besson, 2001: p. 17), because organizational perceptions are associated with desirable outcomes, including the increase in commitment to the work and performance (Chang et al., 2009; Van Kleef et al., 2009). Thus, the performance of a project is the result of the dynamics of the first phase of a transformation established by the management, the perception by the actors of this project and the organizational benefits and freedom of action of the actors. Their perception of this phase is ultimately a critical factor to determine a project's success or failure (Rowe and Besson, 2001: p. 8). However, despite the intuitive appeal of the notion that the perceived transformation will have an impact on the key results, these previous works did not take an interest in the mechanism of such an impact.

The link between "transformation of organizations" and "organizational perception" having been established, we will now focus on the decryption of perception to obtain a more global vision of it. We seek to show that the perception of the first phase of processing is a critical variable in the success of a project.

\section{Organizational Perception}

Perception links the actor to the environment through a moderator: the senses. This perception is mobilized in management to study changing situations. Thus, the psycho-cognitive approach argues that the actors analyze their social environment to identify perceptual signals so as to determine their emotional experience (Efenbein et al, 2007; Davenport and Beck, 2000; Weick et al., 2005). Some psychologists have noticed that emotional experience follows the perception of a stimulus. For example, 
Kelly and Barsade (2001) demonstrate that the interdependence of actors in a workplace results in a high intensity of evocative stimuli. Thus, the three stages of perception highlighted here are revelation, awareness and interpretation.

(I) The revelation occurs when a stimulus is in the scope of a sensory receptor (e.g. vision). The principal dimensions of a stimulus are its novelty, being pleasant and its relevance to the objectives (Efenbein et al, 2007).

(II) The awareness is involved in the interception of the stimuli by sensory organs (Davenport and Beck) organs, 2000.

(III)Finally, the interpretation is the attribution of meaning to a given situation (Weick et al., 2005).

The research-action works by Armenakis et al. $(2007,2002)$ provide an illustration of the emotional experience. They emphasize the importance of the launching message of the transformation. This message communicates the nature of the transformation while inducing some indicative elements (named "feelings") that determine the reactions to change (Armenakis and Harris, 2002: p. 169). The perception through experience shows a dynamic and constructive dimension. More specifically, the authors have five categories of feelings (Armenakis et al, 2007: pp. 276-277):

- The feeling of unconformity (divergence) is the existent perception of a need for change. The unconformity is a gap, a discrepancy, with regards to an acceptable performance. It represents the justification for a strategic change. The identification and mobilization process of these cognitive styles, in a project team for example, allows an assessment of the awareness of the need for change (Armenakis et al, 2007: p. 276). The nonperformance of certain important functions for the organization represents an indication of unconformity. Thus, the unconformity imposes to provide information to the actors explaining why such organizational transformation is necessary.

- The sense of the appropriation is the belief of the actors that a specific organizational transformation will effectively resolve unconformity. This belief is necessary so that they support the transformation. This sense means that the proposed transformation is perceived as appropriate for the concerned organizational context. Indeed, the actors can perceive a need for transformation, but disapprove of the suggested amendment. Studies highlight the importance of confidence in the relevance of the change being implemented. The influence of the reasons given by the manager on the actors reactions is a function of the adequacy or the credibility of the mentioned reason, as well as the sincerity of the manager (Sitkin and Bies, 1993).

- The sense of efficiency is defined as the confidence in the personal and organizational capacities to implement a successful organizational transformation. It is the hope (an effort that will lead to the success of a transformation), the feeling that success is possible, and the hope of achieving the new and necessary skills.

- The main support is the sense of behavioural integrity, meaning the perception of the correspondence between the words and the acts of the leaders. It is defined by the belief that the actors and their immediate manager support the organizational transformation and are motivated to lead it to success. The main support includes the influence of respected colleagues and the networks of interpersonal relationships in an organization.

- The sense of valence refers to the perception of personal benefits (or losses) which can reasonably be expected after an organizational change. This is a motivating factor that refers to the attractiveness of the (perceived or real) outcome associated with the initiative of an organizational change. Indeed, there is 
a link between attitudes toward the work transformations and their expected results. Some extrinsic motivation (for example, financial compensation) can be used to encourage actors to change their behaviour, at least until that the intrinsic value becomes apparent. Thus, a management encouraging the sharing of earnings, for example, provides the extrinsic reward and can be integrated within the change initiatives.

Finally, perception includes the meaning that change represents for leaders and actors, the extent in which they control (information) and the degree of confidence in people that promote the change (Coghlan, 2000). The transformation is evolving on the following continuum: improvement, uncertainty with positive probability, uncertainty with negative probability, threat and destruction. The response of the individual will depend on the assessment of his impact. Confronted with a specific situation, he may deny, dodge, oppose, resist, tolerate, accept or support. Some cognitive bias or aberrations (Sadler-Smith and Shefy, 2004) may then appear in the exchange of views between several actors interacting in a team. These points of view correspond more to an opinion rather than to a real perception of the world.

It is then important to mention the measurement of organizational perception, i.e. the difference between the objective of the change set by management and the perception that the members of the concerned team will have. Therefore, there exists a link between perception, the first phase of organizational transformation and the performance of the project as we seek to illustrate, as this triptych is at the heart of the managers concerns in information systems.

\section{Illustration}

In order to appreciate all the various elements of theoretical currents on perception, allowing assessing organizational transformation, we put forward a mapping of the perception of the first phase of organizational transformation. The suggested model will then be illustrated by two case-studies leading to a discussion.

\section{Proposal of a Perception Model of the First Phase of an Organizational Transformation}

Our visualization of facts has a stimulus for a starting point. The phenomenon of perception can be apprehended at two levels:

(i) the effects of a set of characteristics (situational characteristics of the stimulus and the potential to deal with the situation $^{1}$ ) on perception (structuring the types of perception - by the senses or by experience);

(ii) the effects of this perception on the evaluative judgment of actors for a given organizational transformation (corresponding to attitude and intent).

The evaluative judgment (favourable, reserved or opposed) therefore leads to a certain performance, i.e. a certain faculty to implement actions so as to meet the objectives and to continue reporting the results. To create this mapping as a tool for analysis, the indicators created to address these conceptual dimensions are derived from the works that we presented earlier. Schematically, the visualization of the problem is the following (see figure 1).

\section{Methodology and Analysis of the Results}

To illustrate this approach, going back before the process of transformation, we have chosen to refer to two case-studies to have a critical approach of perceptions,

\footnotetext{
${ }^{1}$ Paul Fraisse (1949) points out the obvious effect of attitudes on perceptual data selection. "The very efficiency of our perceptual activity is dependent on an agreement between our attitude and given factors" (p. 239). Thus, according to the author, the perceptual system must be understood as a function of the personality. "The perceptual processes which are responsible for detecting, selecting and controlling information, are an aspect of the control system which may be called personality" (p. 247).
} 
commitments, incidents and resistances of the actors when confronted to the first phase of organizational transformation. The selection of the following case-studies meets several criteria: they are evocative when it comes to information system practices, they are relatively detailed so as to capture all the organizational dimensions and they are able to help us in the understanding of the links between transformation and perception.

- The data from the first case-study of Alpha Company were collected from a semistructured interview guide that led to question the members of a team facing an organizational transformation in information systems (see Appendix 1). Interviews include issues related to the themes presented in the first part, while respecting the logic and the links of the perceptive model of organizational transformation (figure1).
- The data from the second case-study were recovered from Schebath and Mehmanpazir (2005) studies, detailing the transformation process in information systems. The case-studies are presented in table 1 . The data were analyzed according to the qualitative method of textual analysis (Huberman and Miles, 1991).

The results are presented in the following tables: the characteristics of an organizational transformation (table 2), the characteristics of the stimulus that corresponds to the announcement of the first phase of the transformation (table 3 ), the organizational perception of the first phase of processing (table 4). These tables are organized as follows: the first column sums up the responses provided by the Alpha company actors interviewed on their own ground; the second column gathers the data of the case-study of the CCR foundation (Schebath and Mehmanpazir, 2005).

Figure 1: The Perception of the First Phase of Organizational Transformation

STIMULUS

Triggering the mechanism of perception

\begin{tabular}{|c|c|c|}
\hline \begin{tabular}{l}
\multicolumn{1}{c}{ CHARACTERISTICS } \\
1 / Situation: Dey and \\
Abowd, 1999; Hull and \\
al, 1997 \\
- Place \\
-Actors identity \\
-Activity \\
-Time \\
2 / Stimulus: Frijda, \\
1986; Scherer, 1995 \\
-Novelty \\
-Intensity \\
-Pleasant character \\
-Relevance with regards \\
to the goals to achieve \\
3 / potential to deal \\
with the situation: Cyert \\
and March, 1992; Milton \\
and Westphal, 2005; \\
Rowe and Besson, 2001; \\
Wade, 1996 \\
-Strategic maturity \\
-Identification \\
-Benefit Awareness \\
-Freedom of action \\
-Awareness control \\
-Management style
\end{tabular} & $\begin{array}{l}\text { EVALUATIVE JUDGMENT } \\
\text {-Attitude and intent } \\
\text { toward the first phase of } \\
\text { transformation } \\
\text {-Likelihood of satisfaction }\end{array}$ & $\begin{array}{l}\text { INDICATORS OF } \\
\text { PERCEPTION } \\
\text { By senses: Coghlan, } \\
\text { 2000; Weick et al, } \\
2005 \\
\text {-Revelation } \\
\text {-Attention } \\
\text {-Interpretation } \\
\text {-Cognitive bias } \\
\text { By experience: } \\
\text {-Emotional } \\
\text { experience: Elfenbein } \\
\text { et al, 2007; Armenakis } \\
\text { et al, 2007 } \\
\text {-Memory: Forgas and } \\
\text { George, 2001 }\end{array}$ \\
\hline
\end{tabular}


Table 1: Presentation of Case-studies

\begin{tabular}{|l|l|}
\hline Project & Description \\
\hline Primary data collection \\
\hline 1. & $\begin{array}{l}\text { The questioned company that we shall name Alpha' is the French subsidiary of an } \\
\text { international group specialised in the development of business process } \\
\text { management software. It is a ten-year-old company with approximately 200 } \\
\text { employees; its commercial object is to perform three major development } \\
\text { missions concerning: software, customer support and applied research. The } \\
\text { sector in which it lies in is highly competitive. } \\
\text { The project concerns a micro-transformation: a change of department for the } \\
\text { team and technology for the project that this team is carrying out. }\end{array}$ \\
\hline Secondary data collection \\
\hline 2. & $\begin{array}{l}\text { The C.C.R foundation (Schebath and Mehmanpazir, 2005) is a non-profit making } \\
\text { cultural organisation governed by the 1901 Act. Their main mission is to support } \\
\text { and conduct cultural events (regional theatrical tours, fund management to } \\
\text { support contemporary art, summer animations and the creation of informative } \\
\text { catalogues ....). For some 20 years of existence, it has employed about 30 } \\
\text { employees (p. 3). } \\
\text { The project concerns a macro-transformation: establishment of a new } \\
\text { organizational structure and the acquisition of new computer resources (servers } \\
\text { and computers...). }\end{array}$ \\
\hline
\end{tabular}

${ }^{2}$ For confidentiality reasons 
Table 2: Characteristics of Organizational Transformation

\begin{tabular}{|c|c|}
\hline ALPHA COMPANY & THE CCR FOUNDATION \\
\hline $\begin{array}{l}\text { Situational features of the first phase of the } \\
\text { transformation (contextual approach) }\end{array}$ & $\begin{array}{l}\text { Situational features of the first phase of the } \\
\text { transformation (contextual approach) }\end{array}$ \\
\hline $\begin{array}{l}\text { Place } \\
\text { The transformation takes place in a small team } \\
\text { of a company specialised in the development of } \\
\text { business process management software. } \\
\text { (This project also concerns modules developed } \\
\text { in foreign subsidiaries). }\end{array}$ & $\begin{array}{l}\text { Place } \\
\text { The transformation concerns all the employees of } \\
\text { the association. }\end{array}$ \\
\hline $\begin{array}{l}\text { Identity } \\
\text { The five respondents are executive managers of } \\
\text { the team, having either a degree or a doctorate. } \\
\text { They have a service of } 5 \text { years in the company, } \\
\text { the same rank, for an average of } 40 \text { years of age } \\
\text { and with different past professional } \\
\text { experiences. }\end{array}$ & $\begin{array}{l}\text { Identity } \\
\text { Five people were interviewed by a consulting firm. } \\
\text { The selection is representative of the non-profit } \\
\text { organisation (NPO) (the director, the head in } \\
\text { information system, a department head, a chargé } \\
\text { de mission and a secretary (pp. 11-19) }\end{array}$ \\
\hline $\begin{array}{l}\text { Activity } \\
\text { The members of the team are responsible for } \\
\text { the development of innovative projects in } \\
\text { information system such as the creation of } \\
\text { integrated software modules. }\end{array}$ & $\begin{array}{l}\text { Activity } \\
\text { The employees of the NPO are responsible for the } \\
\text { animation of the cultural life of the region by their } \\
\text { participation and the organisation of cultural } \\
\text { events (p. 3). }\end{array}$ \\
\hline $\begin{array}{l}\text { Time of the transaction } \\
\text { The project was limited in time: it was done } \\
\text { over a period of } 3 \text { years. }\end{array}$ & $\begin{array}{l}\text { Time of the transaction } \\
\text { The project was limited in time: it was done over a } \\
\text { period of one year and a half (p. 11). }\end{array}$ \\
\hline $\begin{array}{c}\text { The potential of the actors and their } \\
\text { preparation }\end{array}$ & $\begin{array}{c}\text { The potential of the actors and their } \\
\text { preparation }\end{array}$ \\
\hline $\begin{array}{l}\text { Strategic maturity of actors } \\
\text { The Alpha corporation has a cross } \\
\text { organizational structure by projects. Therefore, } \\
\text { the activities of the members vary, depending } \\
\text { on the project to which they are assigned. }\end{array}$ & $\begin{array}{l}\text { Strategic maturity of actors } \\
\text { The CCR Foundation is in development. It has a } \\
\text { unit type organization, organized in } 4 \text { autonomous } \\
\text { departments and a universal IT department. The } \\
\text { exchange of information between the departments } \\
\text { is very difficult or non-existent (p. 6, p. 8). There is } \\
\text { "a lack of team spirit" (p. 8), "the current } \\
\text { organisational structure has not favoured the } \\
\text { introduction of rules and habits to create team } \\
\text { work" (p. 8). }\end{array}$ \\
\hline $\begin{array}{l}\text { Identification of actors } \\
\text { The emotional attachment is stronger toward } \\
\text { the corporation than toward the manager of the } \\
\text { team. The extent of the actors' identification to } \\
\text { the company's objectives is assessed through an } \\
\text { annual survey. The themes addressed in this } \\
\text { survey deal with the following points: } 1 \text { / } \\
\text { commitment of the employees defined by "a } \\
\text { combination of attitudes and behavioural } \\
\text { intentions" (concerning commitment, pride of } \\
\text { belonging to the company, loyalty, the defence } \\
\text { of the organization), } 2 \text { / perception of the } \\
\text { company's competitive position and the quality } \\
\text { of its products and services, } 3 \text { / internal work } \\
\text { relations; } 4 \text { / relations with the direct manager, }\end{array}$ & $\begin{array}{l}\text { Identification of actors } \\
\text { The identification of employees is difficult to } \\
\text { apprehend because of the heterogeneity of their } \\
\text { status: CDI (job contract for an indefinite duration: } \\
\text { for managers), CDD (job contract for a set } \\
\text { duration of } 5 \text { years or for recently recruited young } \\
\text { employees), state officials detached for specific } \\
\text { sales campaigns and part time workers in show- } \\
\text { business (for activities to support work-editing, or } \\
\text { to assist work-distribution) (p. 4). }\end{array}$ \\
\hline
\end{tabular}


5 / empowerment of employees, 6 / opportunities for personal development, 7 / evaluation of individual performances as well as the company's, 8 / evaluation of informational process and the evolution assessment of the organizational structure, 9 / innovation, 10 / customer service 11/ understanding of the company's strategy and the business model 12 / balance between work and private life.

Organizational benefits

For this transformation, the mobilized resources are mainly human and financial, and to a lesser extent, technical and computer resources. For the human resources department, this is an important issue, due to the fact that the transformation requires a new definition of the staff's tasks and financially, it involves many budget transfers.

\section{Organizational benefits}

The implementation of the new computer media has benefited from several sources:

-the support of an external consultant specialized in the development of databases, and whose mission was to put in place all the management tools taking into account the necessary data for the various services.

-training courses about certain IT tools for employees (p. 11).

Freedom of action

This transformation was the intention of the sole hierarchy. It is a collaborative project and it is described as an "improvised" initiative by the members of the team who have a total freedom of action to accomplish it. The actors consider that the concept of organizational transformation is primarily an internal change of the organization and the most often cited examples can be grouped into three broad categories: a transformation on a small scale (such as a change of project), on a medium scale (such as a change of department) and on a large scale (such as a change of components, or a change of both department and technology).

Conscious control

The manager hardly ever uses emotions in his management. An average score of 5/20 has been attributed to the following question: does your manager use his emotions in his management?

Management style

Interviewed employees believe that their manager has a "comprehensive" style of management, is open to others and does not employ specific indicators to measure the satisfaction and climate of the team. Thus, there is no interference with the annual analyses distributed by the parent company for all

\section{Freedom of action}

This transformation originated from the will of the managing director supported by the board of directors. This transformation was supervised by a consultant, as far as IT is concerned. The departments were not given any help to coordinate themselves, employees had to use the "D system" (p. 8), that is to say, their own resourcefulness.

\section{Conscious control}

Nothing is said on the emotions of the manager, but "the actors are left to their entire goodwill, or their organization is strongly linked to their past acquired knowledge" (p. 7).

\section{Management style}

The management style is very authoritarian. Employees believe that "it is always the management (of the Foundation or of one of its departments) that "holds the reins" and use their power of decision or their authority to manage missions" (p. 8). crucial importance for them. 
Table 3: Characteristics of the Stimulus

\begin{tabular}{|c|c|}
\hline ALPHA COMPANY & THE CCR FOUNDATION \\
\hline The characteristics of the stimulus & The characteristics of the stimulus \\
\hline $\begin{array}{l}\text { Novelty } \\
\text { The transformation stimulus simultaneously } \\
\text { includes two elements: the change of } \\
\text { department for the team and a new technology } \\
\text { for the project that they must carry out. If the } \\
\text { change of department is easily understood, we } \\
\text { have requested more details about the change } \\
\text { of technology. It consists of a change in the } \\
\text { programming language and of the } \\
\text { technological environment (client-server } \\
\text { technology, Web). }\end{array}$ & $\begin{array}{l}\text { Novelty } \\
\text { The transformation stimulus includes several } \\
\text { elements: the establishment of a new } \\
\text { organizational structure (autonomous } \\
\text { departments), the acquisition of new IT resources } \\
\text { (servers, computers, Ethernet network...) and a } \\
\text { two day-training course for half of the employees. }\end{array}$ \\
\hline $\begin{array}{l}\text { Intensity } \\
\text { Although this is a micro-transformation, the } \\
\text { actors interviewed regarded it as a major one } \\
\text { because it involves, simultaneously for the } \\
\text { team, a change of department and the use of } \\
\text { new technologies. }\end{array}$ & $\begin{array}{l}\text { Intensity } \\
\text { This is a macro-transformation that impacts the } \\
\text { entire organization of the foundation. It is a major } \\
\text { internal transformation which has upset working } \\
\text { relations. }\end{array}$ \\
\hline $\begin{array}{l}\text { Pleasant character } \\
\text { The organizational transformation here has } \\
\text { been implemented to meet a specific and } \\
\text { frequent request: the development and } \\
\text { delivery of a new software. }\end{array}$ & $\begin{array}{l}\text { Pleasant character } \\
\text { This transformation was designed to contribute to } \\
\text { the development of the foundation, which was } \\
\text { meant "to considerably reorient its activities } \\
\text { according to the will of their management and the } \\
\text { growing expectations from the political and } \\
\text { administration actors participating in its financing } \\
\text { (p. 8)." }\end{array}$ \\
\hline $\begin{array}{l}\text { Relevance to the goals } \\
\text { This type of transformation is common in the } \\
\text { company and it corresponds to the company's } \\
\text { objectives, who wish to meet its customers' } \\
\text { expectations. }\end{array}$ & $\begin{array}{l}\text { Relevance to the goals } \\
\text { This transformation was necessary due to } \\
\text { enlargement of the foundation and its new } \\
\text { objectives. }\end{array}$ \\
\hline
\end{tabular}


Table 4: Organizational Perception of the First Phase of Transformation

\begin{tabular}{|c|c|}
\hline ALPHA COMPANY & THE CCR FOUNDATION \\
\hline Perception by senses & Perception by senses \\
\hline $\begin{array}{l}\text { evelation } \\
\text { The announcement of the transformation was } \\
\text { made by the manager of the team } \\
\text { (commissioned by top management) at a } \\
\text { meeting of about } 30 \text { minutes. It was by this } \\
\text { stimulus that team members were informed of } \\
\text { the changes that would affect them. }\end{array}$ & $\begin{array}{l}\text { Revelation } \\
\text { The announcement of the transformation was } \\
\text { made by the managing director in agreement with } \\
\text { the board of directors. All employees were } \\
\text { informed. }\end{array}$ \\
\hline $\begin{array}{l}\text { Attention given to this information the day of the } \\
\text { announcement } \\
\text { Actors focused their attention on this } \\
\text { announcement. }\end{array}$ & $\begin{array}{l}\text { Attention given to this information the day of the } \\
\text { announcement } \\
\text { Actor focused their attention on this } \\
\text { announcement. }\end{array}$ \\
\hline $\begin{array}{l}\text { Interpretation } \\
\text { The team waited for the hierarchy's directives } \\
\text { before starting to change the work organization. } \\
\text { Concerning this transformation in particular, } \\
\text { the actors considered that it was an internal } \\
\text { change, from an organizational origin and close } \\
\text { to an internal restructuring. More specifically, } \\
\text { from a structural point of view, the actors } \\
\text { regarded it as an evolution, and from an } \\
\text { operational point of view, as an innovation (or } \\
\text { regression). However, this transformation will } \\
\text { only impact a part of the organization. }\end{array}$ & $\begin{array}{l}\text { Interpretation } \\
\text { Nothing was proposed to them and they had no } \\
\text { freedom of action. Nothing was undertaken by } \\
\text { them except in case of emergencies, they adopted } \\
\text { the "system D" (p. 10). "Whether it concerns } \\
\text { information processing tools or collaborative work } \\
\text { procedures, nothing is defined, or written." "the } \\
\text { indications given by the managing director or one } \\
\text { of the department's manager, during the period of } \\
\text { the "system D" approach, may delimit the tasks to } \\
\text { carry out for a mission" (p. 10). }\end{array}$ \\
\hline ence & \\
\hline $\begin{array}{l}\text { Description of feelings toward this transfor } \\
\text { If we refer to the analysis of "feel } \\
\text { results show that feelings of discord } \\
\text { "valence" are, for the team, the most im } \\
\text { Divergence comes from a conscious } \\
\text { change. The team and their man } \\
\text { particularly sensitive as to the outcor } \\
\text { project. Nothing alters their motivatic } \\
\text { oriented towards success. } \\
\text { Valence corresponds to the perce } \\
\text { personal benefits from the outcom } \\
\text { organizational transformation. Indee } \\
\text { creative value at the same time for the } \\
\text { for the client and especially for the me } \\
\text { the team who hope to get more ir }\end{array}$ & $\begin{array}{l}\text { escription of feelings toward this transformation } \\
\text { If we refer to the analysis of "feelings", the results } \\
\text { show that feelings of discordance and "valence" are } \\
\text { the most important for the actors. The divergence } \\
\text { comes from the conscious need for change. The } \\
\text { terms used to describe this feeling vary, depending } \\
\text { on the function of the person interviewed. Thus the } \\
\text { managing director expresses himself in financial } \\
\text { terms. He feels that "a return on investment is not } \\
\text { to be expected" and that there was no } \\
\text { "improvements in global performance" (p. 11). The } \\
\text { head of information systems expresses himself in } \\
\text { user's terms. As users do not master technology, he } \\
\text { spends "50\% of his time" assisting them (p. 13). } \\
\text { The head of a department is limiting the uses of } \\
\text { office automation and internal messaging (p. 16). } \\
\text { The project manager, only uses a few of the } \\
\text { computer tools but believes, with his colleagues, } \\
\text { that "they need to be trained or be accompanied } \\
\text { regularly" (p. 18). Finally, the secretary has "the } \\
\text { impression of not knowing how to use the proper } \\
\text { software needed" to the work and feels "a need for } \\
\text { more training" (p. 19). Valence corresponds to the } \\
\text { perception of personal benefits from the } \\
\text { (perceived or real) outcome of the organizational } \\
\text { transformation. The satisfaction that the actors are }\end{array}$ \\
\hline
\end{tabular}




\begin{tabular}{|c|c|}
\hline $\begin{array}{l}\text { control that they hold, at } 70 \% \text {, the degree of } \\
\text { trust granted to the hierarchy, at } 20 \% \text {. }\end{array}$ & $\begin{array}{l}\text { gaining is "very uncertain, according to skills and } \\
\text { availability" (p. 7). }\end{array}$ \\
\hline $\begin{array}{l}\text { Experience of similar experiments (memory) } \\
\text { Although members have already experienced } \\
\text { similar situations (this can be explained by their } \\
\text { cross organizational structure by projects), they } \\
\text { believe that their prior experiences do not } \\
\text { interfere in their reactions to this } \\
\text { transformation and argue that the content of } \\
\text { their actions are renewed with each new } \\
\text { project. }\end{array}$ & $\begin{array}{l}\text { Experience of similar experiments (memory) } \\
\text { The employees questioned had no similar } \\
\text { experience }\end{array}$ \\
\hline Bias and aberrations & Bias and aberrations \\
\hline $\begin{array}{l}\text { Actors consider being sensitive to some } \\
\text { interferences (false rumours, denials, } \\
\text { contradictory announces...), and to some } \\
\text { constraints in the transmission of the message } \\
\text { stimulating the organizational transformation. } \\
\text { They existed since the beginning of the project, to } \\
\text { an acceptable degree, but this fact does not upset } \\
\text { them. }\end{array}$ & $\begin{array}{l}\text { Employees are sensitive to information circulation in } \\
\text { so much as "the lack of collective spirit regularly } \\
\text { causes tensions due to the inability of exchanging } \\
\text { and sharing the information needed for a better } \\
\text { coordination of each other's interventions" (p. 8). }\end{array}$ \\
\hline Evaluative judgment & Evaluative judgment \\
\hline $\begin{array}{l}\text { Evaluation of the transformation project } \\
\text { The project is evaluated with an "uncertain and } \\
\text { positive probability". } \\
\text { The only important thing for the team members } \\
\text { is the outcome of the project. }\end{array}$ & $\begin{array}{l}\text { Evaluation of the transformation project } \\
\text { The project is evaluated with an " uncertain and } \\
\text { positive probability" }\end{array}$ \\
\hline $\begin{array}{l}\text { Attitude and intent } \\
\text { Actors are "tolerant" regarding the } \\
\text { transformation. They intend to carry out the } \\
\text { project totally }\end{array}$ & $\begin{array}{l}\text { Attitude and intent } \\
\text { Actors are quickly discouraged. }\end{array}$ \\
\hline RESULTS & RESULTS \\
\hline $\begin{array}{l}\text { The result of this organizational transformation is } \\
\text { regarded as positive on the short term by actors, } \\
\text { but partial on the medium term. Indeed, the } \\
\text { organizational transformation was perceived } \\
\text { positively because the job could be done under } \\
\text { acceptable conditions and the project was } \\
\text { completed in time. However, new changes in } \\
\text { technology are already programmed in the near } \\
\text { future. }\end{array}$ & $\begin{array}{l}\text { The result is negative for management and very } \\
\text { insufficient for employees. On the long term, the } \\
\text { establishment of this transformation has not } \\
\text { improved their working conditions. On the } \\
\text { contrary, their condition has deteriorated. A } \\
\text { consulting firm responsible for the audit of this } \\
\text { transformation has identified several shortcomings } \\
\text { related to the organizational structure and } \\
\text { methods of work currently in use (p. 8). }\end{array}$ \\
\hline
\end{tabular}




\section{Discussion}

Our research offers the opportunity to illustrate an aspect of the dynamics of information systems in their organizational environment by shedding some light over existing theories: the contextual approach and current research work on leadership.

Our research reflects the existence of a link (which remains to be generalized in future research), between the first phase of an organizational transformation and how the team members perceive the objective that is assigned to them which leads to some form of performance (Chang et al, 2009). On the whole, the results show that the actors commit themselves more strongly if the project can create some personal and collective value. In such a case, their perception seems to impact the manner in which they are going to invest themselves in the project. Secondly, the results of the two case-studies differ when one considers the leadership of the transformation. In the case of the Alpha company, the leader has a comprehensive behaviour. This leader does not seek to maintain the exercise of his control; he has a receptive attitude and shows a certain "latitude" toward the team's anticipated objective. For their part, the team members accept the project without trying to be withdrawn from it. The team seeks to create favourable conditions for the establishment of a new transformation. Thus, the team members take over the transformation positively and feel more concerned with its achievement. In the case of the CCR foundation, the leader only uses his authority and power, and the processing results are not satisfactory. In comparison, transformation leadership borrows conflicting paths, whose social meanings would require to be analyzed more specifically, to understand the processes involved.

Thus, our results highlight that actors organize their sensations, interpret them and complete them thanks to experiences based on their perception of the transformation. Their perception is therefore as important as the study, the prediction of the performance factors and the risks of the transformation. In the responses given by the employees of Alpha company, we can find an attitude of resignation initiating a certain "inertia", which annihilates the actors resistance to change. The fact of being used to changes usually weakens the reaction of the team to new projects but, indirectly, influences more strongly the perception they have of their company in general. This habit originates from the cross organizational structure of this company. The transversal aspect (and with it the frequency of the projects and therefore the constitutions and reconstructions of teams) somehow diminishes the reluctance. They are then replaced by the spirit of overachievement, and by a stimulation linked to a challenge to take up. On the contrary, in the case of the CCR foundation, when these elements are missing and the probabilistic ratio is low, the project is a failure. More generally, these observations may be moderated by influences from minority or majority groups of actors. These influences exist within any company, they originate from different representations of reality and differ in their development, underlying conflicts and their action.

Finally, the theoretical contributions on the evaluative judgment (Coghlan, 2000) highlight regular situations where deviations that create corrective actions are aimed at achieving a certain organizational performance. It is significant to note that the nomenclature of "cognitive assessment" tends to induce a false dichotomy (controlled automatic/registration of the stimulus) where the term "cognitive" suggests that the assessment is verbal, conscious, deliberate, logical and slow (Ellsworth and Scherer, 2003). However, the results of our research show that evaluations, even controlled, can be made very quickly by experienced actors who are able to assess events with the greatest judiciousness in the first phase of a transformation. Thus, if their choices are appropriate, the result of the transformation process can be achieved with some degree of success.

The interest of our model (the assessment of the perception as seen through the eyes of the actors) to organizational 
transformation is then double. Firstly, this approach allows to improve the integration of the various organizational processes and to capitalise experiences. Secondly, it can be a key-element of the decision-making process, when it comes to making the decision to continue with the transformation or not. Indeed, this model implies that the transformation and perception process involves some anticipation and adaptation processes that refer to the concept of perceptual experience. Actors use the information stored (Forgas and George, 2001) to reduce some of the uncertainty. Similarly, intuitive knowledge and immediate understanding (Simon 1989: p. 63) play an important role in the development of a proactive vision.

\section{Conclusion}

Our research underlined several objectives: firstly, the development of a model to understand the perception of the first phase of organizational transformation better; secondly, implementation of a protocol to highlight the major steps that lead to the evaluative judgment of the project; and thirdly a search for the existence of a link between the expression of the team's perception and the success of the project, from which a certain performance of the transformation derives. Built on the concept of transformation and the psycho-cognitive approach of perception, this research demonstrates the need to articulate these two theoretical approaches in a structure describing the management of information systems projects. The illustrative results of our investigation lead to several conclusions. We have shown that the first phase of transformation can be grasped through a collective perception model which allows to take the intentions of the actors into consideration. Once the model is detailed, it may become a significant element of action research projects conducted in information systems. However, at a time when researchers pay more and more attention to the "black box" effects of transformational leadership (Kirkman et al, 2009, Gong et al., 2009), the cultural influences that affect leadership and other phenomena of organizational behaviour remain to be explored.

\section{References}

Abowd, G. D., Dey, A. K., Brown P. J., Davies N., Smith M. \& Steggles P. (1999). "Towards A Better Understanding of Context and Context-Awareness," Proceedings of the 1st international symposium on Handheld and Ubiquitous Computing, Karlsruhe, Germany, pp. $304-307$.

Armenakis, A. A. \& Harris, S.G. (2002). "Crafting a Change Message to Create Transformational Readiness," Journal of Organizational Change Management, 15, 2, pp. 169-183.

PMid:9870010

Armenakis, A. A., Harris, S. G., Cole, M. S., Fillmer, J. L. et Self, D. R. (2007). "A Top Management Team's Reactions to Organizational Transformation: The Diagnostic Benefits of Five Key Change Sentiments," Journal of Change Management, Vol. 7, n 3-4, pp. 273-290. September-December.

Baron, J. N. \& Hannan, M. T. (2002). "Organizational Blueprints for Success in High-Tech Start-Ups: Lessons From the Stanford Project on Emerging Companies," California Management Review, 44(3), pp. 8-36.

PMid:16781379

PMCid:1800827

Bass, B. M. (1985). "Leadership and Performance Beyond Expectations," Free Press/Collier Macmillan. New York. PMid:7681575

Bierly, P. E., Kessler, E. H. \& Christensen, E. W. (2000). "Organizational Learning, Knowledge, and Wisdom," Journal of Organizational Change Management, 13, pp. 595-618.

Burns, J. M. (1978). 'Leadership,' Harper \& Row. New York.

PMid:19109359

Champion, D. \& Stowell, F. A. (2003). "Validating Action Research Field Studies: 
PEArL," Systemic Practice and Action Research, Vol. 16, № 1, pp. 21-36.

PMid:10353129

Chang, C.-H., Rosen, Ch. C. \& Levy, P. E. (2009). "The Relationship Between Perceptions of Organizational Politics and Employee Attitudes, Strain, and Behavior: A Meta-analytic Examination," Academy of Management Journal, Vol. 52, № 4, pp. 779801.

PMid:7479172

Coghlan, D. (2000). 'Perceiving, Evaluating, and Responding to Change. An Interlevel Approach,' Chapitre 20. In: Golembiewski, R. (2000). Handbook of organizational consultation, 2nd ed. Publisher. New York.

Corrigan, P. W., Diwan, S., Campion, J. \& Rashid, F. (2002). "Transformational Leadership and The Mental Health Team," Administration and Policy in Mental Health, 30, pp. 97-108.

PMid:10353126

Cummings, G., Hayduk, L. \& Estabrooks, C. (2005). "Mitigating The Impact of Hospital Restructuring on Nurses: The Responsibility of Emotionally Intelligent Leadership," Nursing Research, 54, pp. 2-12. PMid:11341082

Cyert, R. M. \& March, J. G. (1992). A Behavioral Theory of the Firm. (2nded.). Malden, MA : Blackwell.

PMid:15772212 PMCid:1768857

Davenport, T. H. \& Beck, J. C. (2000). "Getting the Attention You Need," Harvard Business Review, Sept-Oct.

Dhami, M. K., Hertwig, R. \& Hoffrage, U. (2004). "The Role of Representative Design in an Ecological Approach to Cognition," Psychological Bulletin, Vol. 30, n 6, pp. 959988.

Elfenbein, H. A., Polzer, J. T. \& Ambady, N. (2007). "Team Emotion Recognition Accuracy and Team Performance," In N.M. Ashkanasy, W. J. Zerbe, and C. E. J. Härtel (Eds.), Research on emotions in organizations. (Vol. 3, pp. 87-119). Amsterdam: Elsevier.
Elsbach, K. (2006). Organizational Perception Management, LEA'S Organization and Management Series.

Ellsworth, P. C. \& Scherer, K. R. (2003). "Appraisal Processes in Emotion," In R. J. Davidson, K. R. Scherer and H. H. Goldsmith (Eds.), Handbook of affective sciences (pp. 572-595). Oxford, U.K.: Oxford University Press.

Forgas, J. P. \& George, J. M. (2001). "Affective Influences on Judgments and Behaviour in Organizations: An Information Processing Perspective," Organizational Behavior and Human Decision Processes, 86, pp. 3-34.

Fraisse, P. (1949). "L'influence Des Attitudes et de La Personnalité Sur La Perception," L'année psychologique. Vol. 51, $n^{\circ} 1$, pp. $237-248$.

Frijda, N. H. (1986). The Emotions. Cambridge University Press, Cambridge, U.K.

Gellis, Z. D. (2001). 'Social Work Perceptions of Transformational and Transactional Leadership in Healthcare,' Social Work Research, 25, pp. 17-26.

Gilmartin, M. J. \& D'Aunno, T. (2008). "Leadership Research in Healthcare. A Review and Roadmap," The Academy of Management Annals: Lawrence Erlbaum Associates, Vol. 1, pp. 387-438. New York, London.

Golembiewski, R. T. (2000). Handbook of Organizational Consultation, 2nd ed. Publisher. New York.

Gong, Y., Huang, J.-C. \& Farh, J.-L. (2009). "Employee Learning Orientation, Transformational Leadership, and Employee Creativity: The Mediating Role of Employee Creative Self-Efficacy," Academy of Management Journal, Vol. 52, $\mathrm{n}^{\circ} 4$, pp. 765-778.

Haag, C. \& Laroche H., (2009). "Dans le Secret des Comités de Direction, le Rôle des émotions : Proposition d'un Modèle Théorique," Management, 12 (2), pp. 82117. 
Hammer, M. \& Champy, J (1993). 'Reengineering the Corporation: A Manifesto for Business Revolution,' New York, Collins Publishers.

Holt, E.B. (1915). 'The Freudian wish, New York.

Huberman, A. M. \& Miles, M. B. (1991). 'Analyse Des Données Qualitatives: Recueil de Nouvelles Méthodes,' De Bøck Université. Bruxelles.

Hull, R., Neaves, P. \& Bedford-Roberts, J. (1997). "Towards Situated Computing," 1st International Symposium on Wearable Computers, pp. 58-65.

Huy, Q. N. (1999). "Emotional Capability, Emotional Intelligence, and Radical Change," Academy of Management Review, 24, pp. 325-345.

Kan, M. M. \& Parry, K. W. (2004). "Identifying Paradox: A Grounded Theory of Leadership in Overcoming Resistance to Change," Leadership Quarterly, 15, pp. 467491.

Kelly, J. R. \& Barsade, S. G. (2001). "Mood and Emotions in Small Groups and Work Teams," Organizational Behavior \& Human Decision Processes, 86, pp. 99-130.

Kirkman, B. L., Chen, G., Farh, J.-L., Chen, Z. X. \& Lowe, K. B. (2009). "Individual Power Distance Orientation and Follower Reactions to Transformational Leaders: A Cross-Level, Cross-Cultural Examination," Academy of Management Journal, Vol. 52, $\mathrm{n}^{\circ}$ 4, pp. 744-764.

Kivijärvi, H. (1997). "A Substance-TheoryOriented Approach to the Implementation of Organizational DSS," Decision Support Systems, Vol. 20, pp. 215-241.

Leach, L.S. (2005). "Nurse Executive Transformational Leadership and Organizational Commitment," Journal of Nursing Administration, 35, pp. 228-237.

Markus, M. L. \& Tanis, C. (2000). "The Enterprise System Experience: From Adoption to Success," In Framing the domains of IT management, Zmud, R. (ed), Pinnaflex: Cincinnaiti, pp. 173-208.

Milton, L. P. \& Westphal, J. D. (2005). "Identity Confirmation Networks and Cooperation in Work Groups," Academy of Management Journal , Vol. 48, $n^{\circ} 2$, pp. 191212.

Piaget, J. (1967). 'La psychologie de l'intelligence,' Armand Collin.

Powers, W. T. (1973). 'Behaviour - The Control of Perception,' Aldyne. Chicago.

Rosen, C. C., Levy, P. E. \& Hall, R. J. (2006). "Placing Perception of Politics in the Context of the Feedback Environment, Employee Attitudes, and Job Performance," Journal of Applied Psychology, 91, pp. 211220.

Rotundo, M. \& Sackett, P. R. (2002). "The Relative Importance of Task, Citizenship, and Counterproductive Performance to Global Ratings of Job Performance: A Policy-Capturing Approach," Journal of Applied Psychology, 39, pp. 1161-1178.

Rowe, F. \& Besson, P. (2001). 'ERP Project Dynamics and Enacted Dialogue: Perceived Understanding, Perceived Leeway, and the Nature of Task-Related Conflicts,' Database for Advances in Information Systems. October, 1, 2001.

Sadler-Smith, E. \& Shefy, E. (2004). The Intuitive Executive : Understanding and Applying "Gut Feel" in Decision-making. The Academy of Management Executive. The thinking manager's source. Vol 18, $\mathrm{n}^{\circ} 4$, november, pp. 76-91.

Schebath T. \& Mehmanpazir B. (2005). 'La Fondation C.C.R: Changement Organisationnel Et Impact Du SI,' Centrale de Cas et de Médias Pédagogiques, Paris, 22 $\mathrm{p}$.

Simon, H. A. (1976). 'Administrative Behavior,' Free Press, New York, pp. 438448.

Simon, H. A. (1987). "Making Management Decisions: The Role of Intuition and 
17 Journal of Organizational Management Studies

Emotion," Academy of Management Executive, vol. 1, $\mathrm{n}^{\circ} .1$, pp. 57-64.

Sitkin, S. B. \& Bies, R. J. (1993). "Social Accounts in Conflict Situations: Using Explanations to Manage Conflict," Human Relations, 46, pp. 349-370.

Stordeur, S., Vandenberghe, C. \& D'hoore, W. (2000). "Leadership Styles Across Hierarchical Levels in Nursing Departments," Nursing Research, 49, pp. 37-43.

Van der Vegt, G. S. \& Brunderson, J. S. (2005). "Learning and Performance in Multidisciplinary Teams: The Importance of Collective Team Identification," Academy of Management Journal, Vol. 48, $\mathrm{n}^{\circ} 3$, pp. 532-547.

Van Kleef, G. A., Homan, A. C., Beersma, B., Van Knippenberg, D., Van Knippenberg, B. \& Damen, F. (2009). "Searing Sentiment or Cold Calculation? The Effects of Leader Emotional Displays on Team Performance Depend on Follower Epistemic Motivation," Academy of Management Journal, Vol. 52, No. 3, pp. 562-580.

Wade, J. (1996). Changes of Mind: A Holonomic Theory of the Evolution of Consciousness. State University of New York.

Weick, K. E., Sutcliffe, K. M. \& Obstfeld, D. (2005). "Organizing and the Process of Sensemaking," Organization Science, 16, pp. 409-421. 


\section{Appendix 1:}

The interview questions (Note: the explanations and/or relationships with key concepts are presented in a smaller fount and italics)

\section{Contextual Questions}

1. Can you present your business?

(Framework $=$ describe the business, number of employees...)

2. What can you say about its evolution and its important strategies?

(The context (=situational characteristics): situation of the company in its group, with its competitors, and type of strategy)

\section{What can you say about yourself?}

= (Individual characteristic of the actors), $C V$ of the interviewees, situation in the business, rank, position, seniority... (attitude, type of personality...)

4. Can you describe Project X:

(The subject $=$ the stimulus; the stimulus characteristics $=$ characteristics of transformation)

\section{Characteristics of the Transformation}

5. Could the project you are currently working on, be regarded as an organizational transformation?

- (Yes, no, partially)

6. First of all and in a general manner, what is your point of view concerning organizational transformations?

7. More specifically and in a general manner, organizational transformation makes you think of (the closest synonym):

\footnotetext{
- an organizational change, a reengineering of management, structuring-restructuring, a metamorphosis, a second-order change
}

- Please categorize these proposals (from the nearest $=1$ to the remotest $=5$ )

8. How would you define, in a general manner, the idea of "an organizational transformation"?

9. More specifically, (regarding this project in particular) how would you define this transformation?

- from a structural point of view, do you consider it as... an innovation, a mutation, an evolution?

10.Specifically, (regarding this project in particular) how would you define this transformation?

- from the operational point of view do you consider it rather as... an innovation, a mutation, an evolution?

11. What are, for this project, the mobilized resources?

- in terms of human resources.

- in terms of technical and IT resources

- in terms of financial resources

12. Would you say that this project impacts all or a part of the organization?

(Evaluation of the magnitude of the transformation $=$ from a description systemic or incremental)

13. Between these proposals, you would say that this project rather originates from:

- The sole initiative of the hierarchy; a consensus between the hierarchy and managers; an individual project; a collaborative project; a spontaneous initiative; a well thought out initiative; an improvised initiative....

(Evaluation of the intensity of the transformation (of the project) $=$ from $a$ description - reactive, proactive, passive spontaneous, collaborative or dictatorial.) 
Evaluation of the model: with a historical description - research of the origin of the improvisation / formalization stimulus)

14. In a general manner, what is your "management style"?

15. Do you involve your emotions in your management?

(If so, what importance do you grant them? How would you evaluate this importance, giving it a score from 0 (no importance) to 20 (extreme importance)?
16. What are your indicators to assess the satisfaction of your team members?

17. What are your indicators to assess the climate in your team?

18. What are the incentives that you use most to motivate your team?

19. And on the other hand, what are the disciplinary actions that you use the most?

(Latitude $=$ flexibility of a leader and use of his power)

\section{The Perception:}

\begin{tabular}{|c|c|c|c|c|}
\hline & & $\begin{array}{l}\text { At the } \\
\text { beginning }\end{array}$ & 2 weeks/1month & Today \\
\hline \multicolumn{5}{|c|}{$\begin{array}{ll}20 . & \begin{array}{l}\text { What } \% \text { of success have you } \\
\text { assigned to the project? }\end{array} \\
\end{array}$} \\
\hline \multicolumn{5}{|c|}{$\begin{array}{l}\text { 21. What \% of visibility have you } \\
\text { assigned to the project concerning } \\
\text { means / resources provided? }\end{array}$} \\
\hline \multicolumn{5}{|c|}{$\begin{array}{l}\text { 22. What \% of visibility you have } \\
\text { attributed to the project } \\
\text { concerning the time allotted? }\end{array}$} \\
\hline \multicolumn{5}{|c|}{$\begin{array}{l}\text { 23. In } 4 \text { or } 5 \text { key-words can you define } \\
\text { what the project represents for } \\
\text { you? }\end{array}$} \\
\hline \multicolumn{5}{|c|}{$\begin{array}{l}\text { 24. What degree of confidence do you } \\
\text { have in your hierarchy? (answer } \\
\text { on a scale from } 1 \text { to } 5 \text { ) }\end{array}$} \\
\hline \multicolumn{5}{|c|}{$\begin{array}{l}\text { 25. Did you think you had full control } \\
\text { (precisely information control) of } \\
\text { the project? (answer on a scale } \\
\text { from } 1 \text { to 5) }\end{array}$} \\
\hline \multicolumn{5}{|c|}{$\begin{array}{l}\text { 26. Are you happy to participate in } \\
\text { this project? (answer on a scale } \\
\text { from } 1 \text { to } 5 \text { ) }\end{array}$} \\
\hline \multicolumn{5}{|c|}{$\begin{array}{cc}27 . & \text { How do you evaluate the project? } \\
\text { Enhancing, Uncertain, Threatening, Destructive }\end{array}$} \\
\hline \multicolumn{2}{|c|}{$\begin{array}{l}\text { 28. With regards to the project, what } \\
\text { is your point of view? Would say } \\
\text { that you: } \\
\text { - } \quad \text { deny it ? - dodge it? } \\
-\quad \text { oppose it ? - resist it? } \\
-\quad \text { tolerate it ? - accept it? } \\
\text { - } \quad \text { support it ? - embrace it? } \\
\text { Can you describe what your feelings are, } \\
\text { concerning this project? }\end{array}$} & & & \\
\hline
\end{tabular}


29. How were you informed of the transformation? (revelation)

30. How was it presented to you? (revelation)

31. What degree of attention did you grant this information, on the day you got the information? (degree of attention)

(It was just an information among others, we kept on thinking about it all day..., we talked about it with colleagues, we went to talk about it with the hierarchy)
32. How did you interpret this information? (interpretation)

Did you take any immediate initiatives? Did you plan ahead for some future actions..?

33. Had you ever experienced a similar situation?

If so, did it have an influence on your behaviour? (Yes, no, partially) (Memory $=$ is the short-term use of "meaning" for an immediate decision-making process, or the conservation of "meaning" in the long run

\section{Bias and Aberrations:}

\begin{tabular}{|l|}
\hline \multicolumn{1}{|c|}{ 34. Were there any... } \\
\hline - False rumours? \\
- Denials \\
- Rumours \\
- Support / Information / \\
Communication) \\
- Conflicting announcements \\
\hline
\end{tabular}

35. Did the events listed above affect your vision of the project?

\section{Results}

36. What do you think of the outcome of the project? 